Khalfan S. Al Obaidani*

\title{
Translating Terminology in Business Annual Reports (English-Arabic)
}

\begin{abstract}
Business annual reports are financial statements that contain key information about a company's activities. The reports are distributed to interested parties (e.g. stockholders, creditors, financial analysts and customers) to satisfy their information requirements. In Oman, annual business reports are produced in English and translated into Arabic in order to provide Arab readers with vital information about the companies' operations and their financial positions. This article analyzes lexical variations, i.e. financial and business terminologies in both English and Arabic versions of the annual reports. A comparison between the English and Arabic profiles of the reports found that the business terms, e.g. 'currents assets', 'asset impairment' and 'changes in equity' showed less variation than others that occurred more dominantly in earlier Arabic translations. This article contributes to the discipline of Translation Studies (TS) by investigating lexical variations of business terms within sociocultural and ideological contexts in Oman. It attempts to answer the following question, "with respect to business and financial terms, do the Arabic versions of the annual reports reflect the notion of standardization over the course of time in specific industrial domains?' Qualitative methods are applied to compare, describe, and analyze the textual profiles of the two versions of the reports. It concludes that the Arabic business and financial terms have become more widely established over the course of time, thus reflecting the notion of standardization. Finally, this article suggests to integrate textual analysis with sociological input to have more insight into translation agents.
\end{abstract}

\section{Keywords}

business annual reports; financial terminology; genre theory; translation strategies; business communication; Oman

\section{Introduction}

Terminology plays a significant role in producing, circulating and applying correct and concise standardized terms to ensure effective communication in business establishments as a whole. As Pozzi (1996: 71) points out:

Terminology plays a decisive role in technical and scientific communication; the more precise and economic terminology is the more efficient the communication process will be, as there will be no room for subjective interpretations or misinterpretations.

Indeed, both scientific and technical communication demands a consistent use of particular terms. Hence, many institutions and agents who provide terminology for other end-users have to ensure its appropriateness, taking into account its potential application for special purposes and objectives.

Terminology is the collection of technical terms (ten Hacken 2006) which can be analysed from cognitive, linguistic and communicative perspectives. The study of terminology largely points to "systematically identifying, specialized terms in the context in which they are used, analysing the concepts they represent in that context, and creating and standardizing terms if need be, to meet the user need for means of expression" (Dubuc 1997: 4). Nida (1999) argues that in order to select a proper choice of terminology in a particular text, it is thus significant to take into account

\footnotetext{
* Khalfan S. Al Obaidani

Studies and Translation Office

Information Sector

Ministry of Foreign Affairs

PO Box 252, Muscat, Postal Code 100

Oman

khalfan@mofa.gov.om
} 
how key terminologies are dealt with in different texts written by the same author or by other authors on the same or related topics, and it is usually helpful to decide how other translators have treated the same problems.

In the real world, business know-how and 'info-technological' development of societies and nations are expanding rapidly, hence understanding specialised language of particular subject fields, and using business and financial terminology and expressions are considered a big challenge for both agents and the institutions in which entrepreneurs operate. Trosborg/Jørgensen (2005: 7) argue:

[...] the business environment is becoming increasingly more homogeneous as everyone is under some pressure to adapt to sets of internationally agreed standards and contemporary practices introduced to regulate the conduct of the new frontierless global economy. Thus, the world of business is rapidly changing into a smaller place where individuals from different backgrounds and of different nationality develop common generic frames of references for producing and understanding the communication of the market place.

Owing to modernity and the consumption of its hi-tech components around the globe, translation becomes an important tool for creating and transferring key concepts and terminologies between cultures and societies across borders. In the time of globalisation, the use of clear, precise and accurate terminology in a particular subject area (e.g. economy, industry, tourism) has become an essential and complementary element of any effective communication, including business and linguistic skills and communicative competencies.

Business communication incorporates not only different business functions (report to shareholders and government, sale of goods, improvement of efficiency, etc.), but also the transference of important thoughts, messages and information and the comprehension of what is being transmitted. Due to the fact that English is the lingua franca of science, technology and business (Fuertes-Olivera/Nielsen 2014: 215) the major know-how and practises in the field of economy and trade, accompanied by their original terminology, were influenced by English-speaking countries. By providing some examples, this paper will analyse the lexical variations of business terms and the role of social agents (e.g. translators, managers, chairpersons, legal advisors) in standardizing Arabic financial terminology in annual reports published by Oman based companies listed in the stock market.

\section{The Aims of the Study}

This study aims to examine the role of social agents in translating and standardizing business and financial terminology in annual reports. These reports are produced by Omani companies listed on Muscat Security Market (MSM). The study presents a product and process-oriented textual analysis of 144 annual reports published in English and Arabic by different companies which vary in size and organizational structures. In doing so, it aims to make a contribution to the field of Translation Studies (ST).

It is worth noting that financial reporting is imported form the west as an instrumental tool to modernise the business and investment climate in Oman. The lexical variations in the Arabic versions of annual reports, the author will argue, reflect a movement towards standardisation in some business institutions in Oman.

\section{The Corpus of the Study}

The social and economic developments in Oman have been constructed in communication and thus, new or modified forms of discourse and texts have emerged which are used for communicative purposes. These texts are drafted and published in English and Arabic within the country and also for intercultural communication across borders. Local and international companies publish business texts, such as annual reports, which are of particular relevance in the business setting (Al Obaidani 2016). 
Business annual reports are financial and narrative texts which are produced yearly and sent to company's shareholders and various other interested parties, such as employees, potential investors, official entities and the media. The reports assess the year's operations and give useful information about the company's corporate mission, business model, quality of leadership, financial performance and strategic direction. They also facilitate investment opportunities in securities to enhance the national economy, as well as attract potential investors.

In Oman, it is a legal requirement to produce annual reports. The Royal Decree issued in 1998, officially declared the establishment of two governmental institutions, namely the Muscat Security Market (MSM) where all listed securities have to be traded, and the Capital Market Authority (CMA), the regulatory body, which, among other tasks, helps to regulate the issues of transparency and disclosure obligations in the securities market.

Annual reports have a fixed structure; the International Accounting Standards (IFRS), in which Oman is a member, demand that annual report to comprise main sections, i.e. chairperson's statement, a balance sheet, an income statement, a statement of cash flow, accompanying notes, a report of management responsibility, and the auditor's opinion. Most annual reports in Oman contain main sections, namely a statement by the company's chairperson, balance sheet, income statement, statement of cash flow, auditor's report, management discussion \& analysis (MD \& A) and statement of changes in shareholders' equity. These reports contain significant information about trading conditions during the past financial period and likely future developments. The reports also include financial conditions in a given company, such as revenues, expenses, operation and investment activities.

However, the labels of the main sections of the annual reports produced by Muscat based companies were modified in order to fulfil socio-economic requirements in Oman. For example, the section 'accompanying notes' has been changed into 'notes to the financial statements'. This

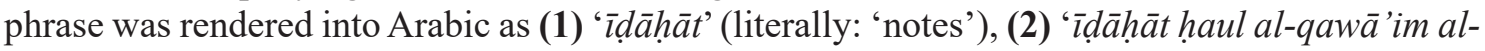
mālìya' (literally: 'notes to the financial statements'), and (3) 'ị̂āhàt haul al-bayānāt al-mālìya' (literally: 'notes to the financial data'). Phrases (2) and (3) were used by Omani companies as standardized terminology over the course of time. By providing some relevant examples, the notion of standardization will be explained in section 5 below.

All annual reports used by the companies are in electronic form on the MSM website ${ }^{1}$, which contains a catalogue of annual reports of the current and previous years to ensure that the highest standards are adopted and implemented, consistent with domestic and international regulatory requirements. For the purpose of this study, this paper will analyse lexical variations, i.e. financial and business terminologies in both English and Arabic versions of the annual reports.

The table below shows all the reports analysed presenting the company's name, date of establishment, company's core activity, number of reports and date of publication.

1 MSM website https://www.msm.gov.om/ [Last accessed 05 January 2017] 


\begin{tabular}{|l|c|c|l|ll|}
\hline Name of the Company & $\begin{array}{l}\text { Date of } \\
\text { Establishment }\end{array}$ & $\begin{array}{l}\text { No. of } \\
\text { Reports }\end{array}$ & $\begin{array}{l}\text { Publication } \\
\text { Date }\end{array}$ & No. of Words \\
Eng Arb
\end{tabular}

Table 1. Companies in the study

The companies mentioned above are categorised as Closed Joint, Stock Companies (SAOG) which are types of business entities in Oman; they are either partially or fully owned by the government of Oman. The SAOG stands for "Societe Anonyme Omanaise Generale". The SAOG companies are listed on the regular stock market, and are responsible for producing annual reports for shareholders and other users.

The corpus of the study comprises 144 annual reports published by Muscat based companies from services sector. The reports were selected from 2001 to 2016. These companies vary in size and organisational patterns.

\section{The Model of the Study}

In this study, qualitative methods were used to compare, describe, and analyse the textual profiles of the original English versions of annual reports and their translations into Arabic. As a result of the comparison, regularities in translation strategies were identified. For describing the strategies, the typology of strategies developed by Chesterman (1997) is used. For instance, the translators of the annual reports apply addition and replacement strategies in order to stabilize and standardize the Arabic accounting terminology over the course of time.

\section{Translation, Social Agents and Standardization}

In an evolving globalized world, translation becomes an essential tool in conveying key concepts and terminology between cultures and societies at large. The reality and structures of different specialized subject areas, such as business, industry, media and tourism, have been accompanied by the emergence of new terminology and definitions for new concepts as our cognitive and epistemological reality changes (Antia 2007: 78).

The translation of financial texts, such as annual reports, plays a significant role in the transmission of key information about business and investment opportunities to Arabic users nationally. Thus, the translation is also informing and influencing the decision-making of the shareholders, as well as enhancing their communication and expectations. That is, without the translation of an-

2 This information is available at http://www.differencebetween.net/business/difference-between-saoc-and-saog [Last access 17 August 2017] 
nual reports, the Arabic shareholders would not be able to make decisions whether to buy shares or not. Whittington (2015: 81) argues that the information contained in annual reports is relevant and "useful in making investment decision".

Translation and text production of annual reports in Oman takes place in national business institutions, that is, Oman based companies listed on the regular financial market, and are responsible for producing annual reports for shareholders and other users (see section 3 above). In addition, these companies contribute significantly to disseminating business views and promoting investment prospects within and across borders through translation work. This is very evident in the standardization process of Arabic financial terms and concepts to ensure effective communication, and to modernize Oman's national economy. As Termmerman/Campenhoudt (2014: 3) argue the realization of standardization of terminology by an authoritative entity has been proved relevant for the transmission of knowledge in a particular linguistic community, or for the development of smaller languages in a variety of scientific, technological and formal fields. This is very evident in the new terminology and concepts that has been introduced to the Arabic financial reporting over the course of many years in particular companies. At the semantic level, for instance, the entire section of the 'report to corporate governance' was added/included in the later versions (2003 onwards) of the annual reports to keep pace with the economic developments in the country, and to implement the laws of the regulatory bodies.

In these Oman based companies, translations are produced by different social agents (e.g. translators, managers, employees, chairpersons) who play a significant role in setting up new domestic laws, such as the Capital Market Authority (CMA), applying international standards and principles (e.g. IFRS), and introducing new terminology to Arab audiences. Although there is a harmonization process between the local/national regulatory body (e.g. CMA) and IFRS, the insertion of new terminology and concepts in both English and Arabic versions of the annual reports is bound by national legal systems and traditional cultures. For example, the English sections and headings of annual reports are slightly modified when they were translated into Arabic in order to conform with the linguistic structure, form and style of the Arabic language to fulfil the standardization objectives over the course of time.

The translation of annual reports is mainly carried out by in-house non-professional translators who came from different Arab countries and have different cultural and educational background. For example, most translators are specialized in finance and business management, and few of them have training courses in the field of Translation (Al Obaidani 2014: 186). This is very evident in the addition and omission strategies of words and phrases reflected particularly in the Arabic versions of annual reports. Indeed, lack of linguistic and communicative competencies among translators can, however, lead to lexical variations and ultimately obstruct the process of standardization in financial reporting at large.

Hence, social agents, including non-professional translators who take part in the translation of annual reports from English into Arabic encounter a number of problems pertaining, for instance, to standardisation and lexical variations. The textual analysis shows that there are more lexical variations of Arabic terms in earlier years and then these terms, as reflected mainly in Arabic versions, became more standardized in the course of time and across the annual reports. The variations and the process of standardization in specific corporate institutions, emphasise the central role translation plays in establishing financial terminology in Arabic. The translational process, in financial reporting, takes the form of collaboration and communication (Al Obaidani 2014: 33), for instance, between various social agents, such as translators, managers, supervisors, employees and chairpersons.

Translators of the annual reports use bilingual electronic, printed and online internet accounting dictionaries that provide meaning of business and accounting terms (Al Obaidani 2014: 36). The internet dictionaries are widely used by translators, which are designed to cater for heterogeneous groups, such as experts, apprentices, trainees, linguists, translators, journalists, students and researchers. As Nielsen/Mourier (2007: 119) point out internet dictionaries provide users with 
more information than the printed ones. The function and scope of the dictionaries varies broadly, for instance, some (e.g. Lexicool, Proz) contain a fix number of different accounting terminology and other dictionaries (e.g. Bab.La) focus rather on accounting and general words.

\begin{tabular}{|l|l|l|}
\hline TERM & ALMAANY & GLOBSE \\
\hline Current Assets & $\begin{array}{l}\text { ○ Ușūl Jārya } \\
\text { al-Maujūdāt/al-Ușūl al-Jārya }\end{array}$ & $\begin{array}{l}\circ \text { Ușūl Mutadāwūla } \\
\circ\end{array}$ \\
\hline Asset Impāl Jārya
\end{tabular}

Table 2. Terms in the study as rendered in Arabic by the internet dictionaries

Few dictionaries (e.g. Glosbe, Reverso) have relied on a corpus for lemma selection, as well as financial statements in conventional annual reports. Many dictionaries (e.g. AlMaany) contain definitions that show both fix/core words and synonyms of the same term. The table above shows the English terms in the study and their translation equivalents in Arabic. Both AlManny and Glosbe dictionaries list more than one meaning (synonyms) for the term current assets. Whereas, AlManny gave a fix Arabic meaning for the terms asset impairment and changes in equity respectively.

It can be observed that some of the terms mentioned in Globse are imprecise. For example,

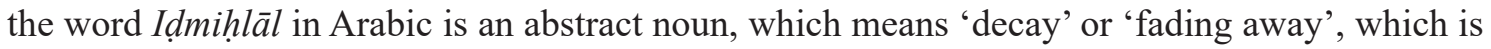
not an accurate translation equivalent for the English accounting term 'asset impairment'. Moreover, the Arabic term taḡayyurāt fi ra's al-māl al-sahmi is not an accurate rendition of the English accounting term 'changes in equity' as the dictionary add the Arabic word ra's al-māl (literally: 'Capital') which deprive such term of its intended meaning. By and large, bilingual lexicographers (e.g. English-Arabic-English) contribute substantially to the process and product of word creation in the target language (TL), especially when the terminology of the latter are being coined on the basis of the source language (SL) (Ali and Saeed 2005: 22).

In general, the lexical variations of accounting terms, which are reflected in the Arabic versions of the reports, reveal the ongoing process of economic changes in the business setting in Oman. Due to the generative nature of terminology (Faber 2012, Berry 2010, Antia 2007), the data analysis indicates that the Arabic versions have constantly acquired new terminologies over the course of time, owing to the social needs in the sphere of business and finance, that is, to promote the investment climate in Oman, and to invite wider Arab readers of the reports to get involved in the buying and selling of shares of the stocks.

The following section will analyse three financial labels, which are illustrated with examples extracted from the database: 'Current Assets', 'Asset, Impairment' and 'Changes in Equity'. These labels represent, among others things, key terminology in annual reports published by companies shown in Table 1 above. Based on the comparison between the English and Arabic versions of the reports, it has been found that these financial terminology showed more variations than others that occurred more dominantly in earlier Arabic translations. It has been argued that lexical variations reflect the process of standardization in specific corporate institutions that emphasise the central role translation plays in establishing financial terminology and concepts in Arabic. 


\subsection{Current Assets}

The term 'Current Assets', which literally means economic and financial resources (e.g. cash, marketable securities, accounts receivable and inventory) refers to the assets that can be converted into cash within one year without undergoing a diminution in value and disrupting the operation of the firm (Khan 2004). This term has been stated in all annual reports as prescribed by the IFRS reporting system in which Oman is a member. However, translators who engage in translating IFRS they should not only have good command both in English and Arabic, but also good and profound knowledge of the technical aspects of the IFRS to ensure the concepts/terms, which have been rendered in Arabic, are accurate, clear, informative and consistent. This will help to stabilize the financial terms of the annual reports and hence fulfil the process of standardization over time. In addition, the translation of IFRS take the form of collaboration between various agents, mainly government bodies (Hameed 2014: 4) and audit firms. For example, the Central Bank of Oman (CBO) issued a circular ${ }^{3}$ demands that all companies and financial services industry (e.g. banks) should implement the changes in IFRS, in order to promote consistency of application, facilitate greater compatibility across the financial sector and address supervisory concerns. Further research can look at the translation of IFRS into Arabic and its significance in standardizing Arabic terminology in financial reporting system in particular and national accounting at large.

The term 'Current Assets', which is used in the 'balance sheet' and 'notes to the financial statements', has been rendered in Arabic as 'al-Ușūl al-Jārya' (literally: 'Current Assets') and 'alUșūl al-Mutadāwūla' (literally: 'Current Assets'). The Arabic terms al-Jārya and al-Mutadāwūla, which mean current in English, are semantically related words, i.e. synonyms. In Arabic, the notion of synonyms has different expressive meanings even though they share a propositional meaning (Najjar 2014: 29). The English-Arabic internet accounting dictionaries (e.g. AlMaany) has two different meanings for current assets, i.e. 'al-Ușūl al-Jārya' (literally: 'Current Assets') and 'al-Maujūiāt al-Jārya' (literally: 'Current Assets'). The terms 'ușūl' and 'maujūdāt', which means assets in English, are synonyms. Thus, we have to make a choice between synonyms as we cannot overload user/readers with two terms for core concept (Berry 2010: 92).

\begin{tabular}{|l|l|c|c|c|}
\hline \multicolumn{2}{|c|}{ TERM } & $\begin{array}{c}\text { al-Ușūl } \\
\text { al-Mutadāwūla }\end{array}$ & $\begin{array}{c}\text { al-Maujūdāt } \\
\text { al-Mutadāwūla }\end{array}$ & $\begin{array}{c}\text { al-Ușūl } \\
\text { al-Jārya }\end{array}$ \\
\cline { 1 - 2 } REPORT & DATE & 3 & - & - \\
\hline SOMS & 2002 & - & 3 & - \\
\hline SOMS & 2005 & - & - & 2 \\
\hline SOMS & 2008 & - & - & \\
\hline
\end{tabular}

Table 3. No. of occurrences of the Arabic term current assets over the course of time

The textual analysis shows that there are variations in using 'Current Assets' in annual reports as a whole. As the table above illustrated, the English term current assets was rendered in Arabic differently over the course of time in a specific company. The lexical item 'al-Maujūiāt alMutadāwüla' (literally: 'Current Assets') was used in three companies, i.e. APBS, OIFC. Moreover, the synonyms 'ușūl' and 'maujūdāt' was used in SOMS Company over the course of time. In other words, the Company used both 'ușūl' and 'maujūdāt' interchangeably from 2001 until 2007, but from 2008 onward 'maujūdāt' was replaced by the term 'uṣull', as the examples below show:

3 Circular No. BM 1149, Central Bank of Oman (CBO), published on 13 April 2017: http://www.cbo-oman.org/circulars/2017/CBOBM1149Apr17.pdf [Last accessed 26 February 2018]. 
(1)

$(\text { ST })^{4}$ Current Assets [SOMS_2002, Balance Sheet: p.3]

$(\mathrm{TT})^{5}$ al-Ușūl al-Mutadāwūla

[Gloss] Current Assets

(2)

(ST) Current Assets [SOMS_2005, Balance Sheet: p.1]

(TT) al-Maujūdāt al-Mutadāwūla

[Gloss] Current Assets

(3)

(ST) Current Assets [SOMS_2008, Balance Sheet: p.1]

(TT) al-Ușūl al-Jārya

[Gloss] Current Assets

In Arabic, the terms 'ușull' and 'maujūdāt' have diverse general meanings, such as stocks, supplies, and properties. However, the detailed analysis showed that, in most cases, there is consistency in the individual reports (i.e. AJSS, OFMI, PSCS and UESC) with regard to 'Current Assets'. This indicates that social agents, including translators, managers and chairpersons have contributed to stabilizing the use of financial terminology over the course of time through translation work.

\subsection{Asset Impairment}

The term 'Asset Impairment' refers to the asset that has a market price lower than the value reported in the balance sheet (Nikolai et al. 2007/2010). This term was included in 136 annual reports. 'Asset Impairment', which is primarily integrated in the balance sheet and notes to the financial statements of the reports, has been rendered into Arabic as (1) 'Inkifäd al-Maujūdāt' (literally: 'Decrease in Assets'), (2) 'Inkifạ̣̈̂ qimat al-Maujūdāt al-Mãlìya' (literally: 'Decrease in the Value of Financial Assets), 'Inkifạd qimat al-Ușull' (literally: 'Decrease in the Value of Assets'), and (3) 'Tadahuur al-Qima fì al-Ușūl al-Mālìya' (literally 'Deterioration in the Value of Financial Assets').

AlMaany internet accounting dictionary has a fix/core meaning for asset impairment, i.e. 'Naqș Qimat al-Ușūl' (literally: 'Decrease of Value of Assets'), whereas Globse (see table 2) and other dictionaries gave more than one meaning for the term 'asset impairment'. The terms 'naqș' and 'inkifäḍ', which means decrease in English, are synonyms. Whereas, the term 'tadahuur', which means deterioration in English, reflects negative connotation in Arabic which implies that the assets are going from bad to worse.

\begin{tabular}{|l|l|c|c|c|c|}
\hline \multicolumn{2}{|c|}{ TERM } & $\begin{array}{c}\text { Tadahuur al- } \\
\text { Qima fī al-Ușūl } \\
\text { al-Mālīya }\end{array}$ & $\begin{array}{c}\text { Tadahuur al- } \\
\text { Qima fĩ al-Ușūl } \\
\text { al-Mālīya }\end{array}$ & $\begin{array}{c}\text { Inkifāọ̆ qimat } \\
\text { al- Ușūl } \\
\text { al-Mālīya }\end{array}$ & $\begin{array}{c}\text { Inkifiāọ qimat } \\
\text { al- Ușūl } \\
\text { al-Mālīya }\end{array}$ \\
\hline OFM & 2003 & 5 & - & - & - \\
\hline OFM & 2004 & - & 5 & - & - \\
\hline OFM & 2008 & - & - & 4 & \\
\hline OFM & 2012 & - & - & - & 3 \\
\hline
\end{tabular}

Table 4. No. of occurrences of the Arabic term asset impairment over the course of time

4 Source Text (ST)

5 Target Text (TT) 
OFM Company, for instance, uses different lexical items for 'Asset Impairment' in the Arabic versions, particularly in the reports published from 2001 to 2007, whereas the term 'asset impairment' becomes standardized from 2008 onward (see table above), as noted in the examples below:

(4)

(ST) At each balance sheet date, the Group assesses if there is any objective evidence indicating impairment of financial assets carried at cost or non-collectability of receivables [OFM_2003, Notes to the Financial Statements: p.9]

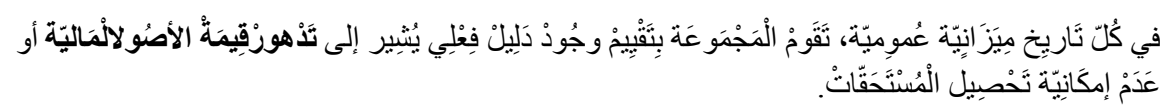

[Gloss] At each balance sheet date, the Group assesses whether there is any physical evidence that indicates a deterioration in the value of the financial assets or the inability to collect the receivables.

(5)

(ST) At each balance sheet date, the Group assesses if there is any objective evidence indicating impairment of financial assets carried at cost or non-collectability of receivables [OFM_2005, Notes to the Financial Statements: p.9]

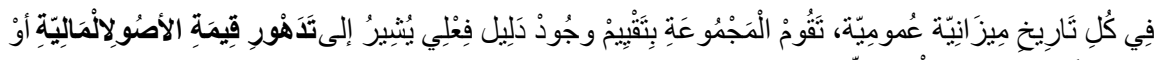

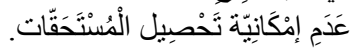

[Gloss] At each balance sheet date, the Group assesses whether there is any physical evidence that indicates a deterioration in the value of the financial assets or the inability to collect the receivables.

(ST) At each balance sheet date, the Group's management assesses if there is any objective evidence indicating impairment of financial assets carried at cost or non-collectability of receivables [OFM_2008, Notes to the Financial Statements: p.5]

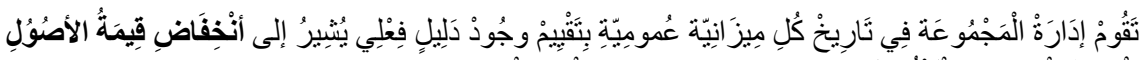

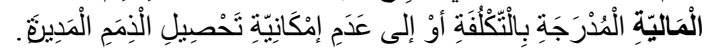

[Gloss] The Group's management at each balance sheet date assesses if there is an objective evidence that indicates a decrease in the value of financial assets carried at cost or the inability to collect receivables.

(ST) At the end of each reporting period, the Management assesses if there is any objective evidence indicating impairment of the financial assets carried at cost or non-collectability of receivables [OFM_2012, Notes to the Financial Statements: p.13]

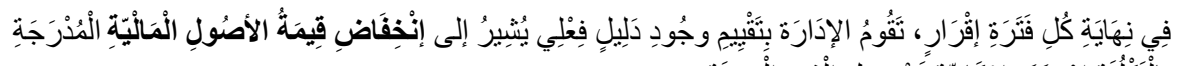

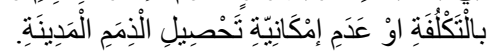

[Gloss] At the end of each period of approval, the Administration assesses if there is an objective evidence, indicating a decrease in the value of financial assets carried at cost value, or the inability to collect receivables.

The analysis above shows that the Arabic versions of the reports produced by OFM Company applied two terms, i.e. 'Tadahuur' (literally: 'Deterioration') and 'Inkifäd' (literally: 'Decrease') over the course of time; this reflects a movement towards standardization in a given institution in 
Oman. Moreover, the social agents chose to add the term 'financial' in both English and Arabic versions of the reports with regard to the terminology 'asset impairment', which is slightly different from the definition indicated in the English-Arabic accounting dictionaries. As FernándezSilva et al. (2014: 189) argue that instead of using the correct terminological expression for a precise concept, an expert in a particular field "might choose another term reflecting a slight shift in this concept's meaning". This shift in the term/concept reveals the significant role social agents play in establishing and standardizing business terminology in Arabic.

\subsection{Changes in Equity}

The term 'Changes in Equity' refer to the changes in company's share capital, accumulated reserves and retained earnings over the reporting period (Everingham and Kana, 2008). 'Changes in Equity' is a primary statement in annual reports, as it explains how equity has changed from one financial year to the other as an outcome of profit, capital contributions and drawings (Codewickx et al. 2007).

The lexical item, 'Changes in Equity', occurs in most annual reports and is rendered as (1)

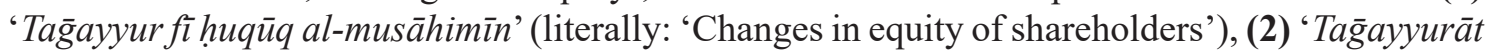
fì huqūq al-milkīya' (literally: 'Changes in equity'), and (3) 'Taḡayyurāt fì amwāl al-musāhimīn' (literally: 'Changes in shareholders' funds'). The English-Arabic internet accounting dictionaries, e.g. AlMaany states one meaning for the term changes in equity' (see table 2 above), while other dictionaries (e.g. Globse, Reverso) mentioned different meanings for the term. The table below demonstrates that there are variations in using 'changes in equity' in annual reports over the course of time.

\begin{tabular}{|l|l|c|c|c|c|}
\hline \multicolumn{2}{|c|}{ TERM } & $\begin{array}{c}\text { Taḡayyurāt fī } \\
\text { huqūq al- } \\
\text { musāhimīn }\end{array}$ & $\begin{array}{c}\text { Taḡayyurāt fī } \\
\text { ḥuqūq al- } \\
\text { musāhimīn }\end{array}$ & $\begin{array}{c}\text { Taḡayyurāt fī } \\
\text { huqūq al- } \\
\text { milkīya }\end{array}$ & $\begin{array}{c}\text { Taḡayyurāt fī } \\
\text { huqūq al- } \\
\text { milkīya }\end{array}$ \\
\hline OFM & 2002 & 2 & - & - & - \\
\hline OFM & 2007 & - & 2 & - & - \\
\hline OFM & 2012 & - & - & 2 & \\
\hline OFM & 2015 & - & - & - & 2 \\
\hline
\end{tabular}

Table 5. No. of occurrences of the Arabic term changes in equity over the course of time

In OFM, for instance, the lexical item, 'Taḡayyurāt fì huqūq al-musāhimīn' (literally: 'Changes in equity of shareholders') and 'Taḡayyurāt fi amwāl al-musāhimīn' (literally: Changes in shareholders' funds') were used in the earlier texts produced from 2001 to 2007, but is no longer used in the later texts published from 2008 to 2016; however, the two terms mentioned above were replaced by the term 'Tagayyurāt fi huqūq al-milkīya' (literally: 'Changes in Equity') instead, specifically in the Arabic version of the annual reports, as the following examples illustrated:

(8)

(ST) The effect of this change in accounting policy has been recorded as an addition to retained earnings of RO 164,000 in the Parent Company's statement of changes in shareholder's equity for the year ended 30 June 2002 [OFM_2002, Notes to the Financial Statements: p.15]

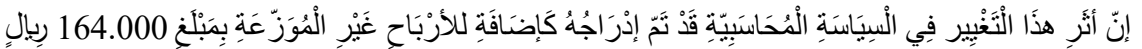

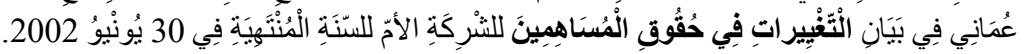


[Gloss] The effect of this change in accounting policy was included as an addition to the undistributed profits of RO 164,000 in the statement of changes in equity of shareholders for the parent company for the year ended 30 June 2002.

(9)

(ST) Gains and losses on remeasurement are reported in the statement of income. Other investments, other than the above and investments held to maturity are classified as available for sale and fair value changes recognised directly in the statement of changes in equity [OFM_2007, Notes to the Financial Statements: p.5]

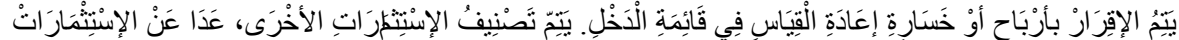

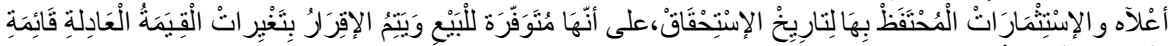

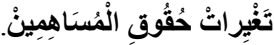

[Gloss] The gain or loss of the re-measurement is recognized in the statement of income, except for investments above, and investments held to maturity, are classified as available for sale and fair value changes are recognized directly in the statement of changes in equity.

(ST) As a result the Company presents in the statement of changes in equity all owner changes in equity, whereas all non-owner changes in equity are presented in the statement of comprehensive income [OFM_2012, Notes to the Financial Statements: p.2].

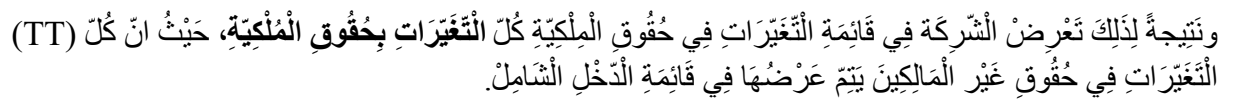

[Gloss] As a consequence, the Company shows in the statement of changes in equity all changes in equity, as all changes in non-owner's equity are recognized in the statement of comprehensive income.

(ST) The changes in subsidiaries are classified as available for sale and fair value changes are recognized directly in the statement of changes in equity [OFM_2015, Notes to the Financial Statements: p.12].

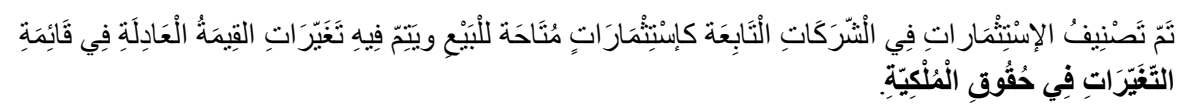

[Gloss] Investments in subsidiaries are classified as available-for-sale investments and changes in fair value are recognized in the statement of changes in equity.

The examples above reflect a process of standardization in respect of 'Taḡayyurāt fi huquiq almilkiya' (literally: 'Changes in Equity'), which is also consistent with some English-Arabic internet accounting dictionaries (e.g. AlMaany, Lexicool). Hence, there has been relative stability in the use of Arabic and English terminology 'Changes in Equity', and its application over the course of time is reflected in examples 8,9 and 10. This stability is attributed to the social agents' efforts to avoid terminological and conceptual ambiguity and misunderstandings in annual reports which can have investment decision-making implications.

\section{Conclusion}

The comparative detailed analysis showed that there are more lexical variations in the Arabic versions texts of the annual reports with respect to business and financial terms (e.g. 'al-ușūl al-

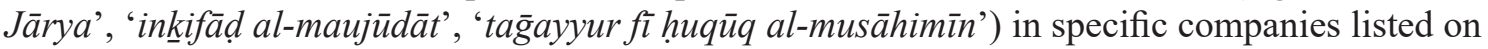


Muscat Security Market (MSM) in Oman. These lexical changes reflected the movement process of standardization over the course of time.

The data analysis indicated that the Arabic versions of the annual reports have constantly acquired new terms in the sphere of business and finance in Oman over the course of time. Owing to the business and economic developments in Oman, more corporate labels and terms were used in the business setting to keep abreast of the latest technological and economic developments across the globe in order to fulfil social requirements and promote the image of the corporate institutions.

It has been found here that the Arabic business and financial terms analysed have become more widely established over the course of many years in the companies mentioned in Table 1 above. Hence, consistency and standardisation process of specific business terms help to avoid confusion and ambiguity among potential and existing Arab shareholders domestically and internationally. The process also emphasised the important role translation and social agents play in establishing business terminologies in Arabic.

\section{Limitation and Further Research}

The major limitation of this paper is that it lacks empirical and sociological methods. This could help to investigate, for instance, if inconsistency in translating financial and business terms inform and influence the conscious decision-making process of shareholders and other users of the annual reports.

\section{Acknowledgments}

I would like to thank the anonymous reviewers for their insightful comments and suggestions that greatly help to improve the final version of the paper. I would also like to thank the Editor Dr Patrick for his contacts and coordination during the review process.

\section{References}

Al Obaidani, Khalfan 2014: Ideological aspects of the translation of business annual reports in Oman (English-Arabic). (Unpublished doctoral dissertation). Aston University, Birmingham, United Kingdom.

Ali, Abdul Sahib/Saeed, Aziz 2005: Specialized meaning presentation in English-Arabic bilingual dictionaries. In turjuman 14, 1, 11-28.

Antia, Bassey (ed.) 2007: Indeterminacy in terminology and LSP: Studies in Honour of Heribert Picht. Amsterdam: Benjamins.

Berry, Roger 2010: Terminology in English Language Teaching: Nature and Use. New York: P. Lang.

Chesterman, Andrew 1997: Memes of translation. Amsterdam and Philadelphia: John Benjamins.

Codewickx, Esther et al. 2007: Fresh Perspectives Financial Accounting. Cape Town: Maskew Miller Longman.

Dubuc, Robert 1997: Terminology: a practical approach. adapted by E. Kennedy. Québec: LinguaTech éditeur.

Everingham, Geoff/Kana, Suresh 2008: Corporate reporting. 8th ed. Cape Town: Juta and Co Ltd.

Faber, Pamela (ed.) 2012: A cognitive linguistics view of terminology and specialized language. Berlin: Den Gruyter.

Fernández-Silva, Sabela/Cabré, Judit 2014: A method for analysing the dynamics of naming from a monolingual and multilingual perspective. In: Temmerman, Rita/Campenhoudt, Marc (eds.), Dynamics and terminology: an interdisciplinary perspective on monolingual and multilingual culture-bound communication. Amsterdam: Benjamins, 183-214.

Fuertes-Olivera, Pedro/Nielsen, Sandro 2014: The dynamics of accounting terms in a globalized environment: The role of English as Lingua Franca. In: Temmerman, Rita/Campenhoudt, Marc (eds.), Dynamics and terminology: an interdisciplinary perspective on monolingual and multilingual culture-bound communication. Amsterdam: Benjamins, 215-233

Hacken, Puis (ed.) 2006: Terminology, computing and translation. Tübingen: Gunter Narr Verlag.

Hameed, Munawar 2014: Application of international financial reporting standards in Oman: A way forward to improve the economy of young Oman, Conference on Oman Economy Contributions from Higher Education, Muscat, Oman, April 8-9, 2014. 
Khan, M Y/ Jain, P K 2004: Financial management: text, problems and cases. 4th ed. New Delhi: Tata McGraw-Hill.

Luzón, María (2005): Genre Analysis in Technical Communication. In IEEE Transactions on Professional Communication 48, 3, 1-11.

Najjar, Ibrahim 2014: The translation of lexical and morphological repetitions in the Arabic novel thartharah fawq alnel into the English adrift on the nile. Master's dissertation, Kuala Lumpur: University of Malaya (Unpublished).

Nida, Eugene 1999: The role of contexts in translating. In: Anderman, Gunilla/Rogers, Margaret (eds.), Word, text, translation. Clevendon: Multilingual Matters, 79-83.

Nielsen, Sandro/Mourier, Lise 2007: Design of a function-based internet accounting dictionary. In: Gottlieb, Henrik/ Mugensen, Jens Erik (eds.), Dictionary, Visions, Research and Practice. Amsterdam: Benjamins, 119-135.

Nikolai, Loren et al. 2007/2010: Intermediate accounting (Book only). 11th ed. Stamford: Cengage Learning.

Pozzi, Maria 1996: Quality assurance of terminology available on the international computer networks. In Somers, Herold (ed.), Terminology, LSP, and Translation: studies in language engineering in honour of Juan C. Sager. Amsterdam and Philadelphia: John Benjamins, 67-82.

Temmerman, Rita/Campenhoudt, Marc 2014: Dynamics and terminology: an interdisciplinary perspective on monolingual and multilingual culture-bound communication. Introduction. In: Temmerman/Campenhoudt (eds.), Dynamics and terminology: an interdisciplinary perspective on monolingual and multilingual culture-bound communication. Amsterdam: Benjamins, 1-16

Trosborg, Anna/Jørgensen, Poul (eds.) 2005: Business discourse: texts and contexts (Linguistic Insights). Berlin: Perer Lang AG.

Whittington, O. Ray 2015: CPA excel exam review: study guide July 2015, financial accounting reporting. New Jersey: John Wiley. 